\title{
As Condições Sociais da Ação Instrumental: Problemas na Concepção Sociológica da Teoria da Escolha Racional*
}

Bruno Sciberras de Carvalho

E m geral, as proposições da teoria da escolha racional aparecem vinculadas a temáticas políticas expostas, sobretudo, pelos precursores Kenneth Arrow, Anthony Downs, James Buchanan e Mancur Olson. Nesse sentido, as concepções centrais da teoria, provenientes da tradição do pensamento econômico, servem para demonstrar que as possibilidades normais de interação política teriam suporte em grupos de interesse que intentam benefícios particularistas e em partidos que maximizam votos. Por outro lado, tem alcançado relevância nos últimos anos, no próprio campo da escolha racional, uma literatura que articula a noção de racionalidade instrumental ao exame de questões e problemas sociais que ultrapassam os limites da prática política. A temática das normas sociais inaugura uma teoria da ação que relaciona a orientação instrumental com a idéia de uma estrutura social controlada pelos agentes, de modo que se entende o quadro societal como um jogo estratégico. O objeto analítico da concepção sociológica da escolha racional refere-se aos bens ou atividades humanas que não são comparáveis e não podem ser estudados, exclusivamente, de acordo com a ciência econômica tradicional, que vê as situações sociais como generalizações de decisões tomadas por sujeitos isolados. Assume-se a

\footnotetext{
*Este artigo é uma versão reelaborada do capítulo III de minha tese de doutorado A Escolha Racional como Teoria Social e Política: Uma Interpretação Crítica. A pesquisa contou com o apoio da Fundação de Amparo à Pesquisa do Estado do Rio de Janeiro - FAPERJ e da Coordenação de Aperfeiçoamento de Pessoal de Nível Superior - Capes.
}

DADOS - Revista de Ciências Sociais, Rio de Janeiro, Vol. 50, n-4, 2007, pp. 827 a 862. 
necessidade de uma nova abordagem de comportamentos que são ao mesmo tempo racionais e não-econômicos (Elster, 1984:127). O ponto original ressaltado é o fato de não se recorrer, ao contrário do pensamento social padrão, às restrições culturais, à tradição, ao acaso ou a estruturas que seriam apenas imaginárias. Os fenômenos sociais são analisados por meio da percepção das normas e dos valores que estão inseridos em complexos mecanismos de troca, diretamente vinculados aos interesses dos agentes.

O projeto essencial da teoria sociológica da escolha racional é fundar uma análise que examine de forma coerente os movimentos do nível macro do jogo social para o micro das ações econômicas, e, inversamente, do micro para o macro. O objetivo é entender as relações sociais como um jogo dependente das práticas racionais, baseado na compreensão segundo a qual os indivíduos participam livremente e ativamente da construção estrutural da sociedade, vista como um conjunto de regras que limitam, mas não constituem, as interações. Assim, a proposição sociológica é estudar as regras que, contratualmente estabelecidas, organizam as ações e que são, posteriormente, modificadas e desenvolvidas no movimento estratégico do jogo social. A necessidade da análise dessas regras sobressai no momento em que as trocas interpessoais revelam grandes diferenças de recursos, originadas pelas variadas posições sociais dos indivíduos. A admissão da vida social como um jogo evidencia o postulado de um espaço de carência e de disputa por bens raros. Por conseguinte, a sociedade é vista como sinônimo de organização de interesses em conflito. Mais especificamente, a estrutura social relaciona-se com o mecanismo de troca ocorrida no mercado da seguinte forma:

"[...] a troca social muitas vezes ocorre não em transações isoladas de duas pessoas, mas dentro do contexto de sistemas de troca em que há competição por recursos escassos. Esses mercados sociais lembram, por vezes, mercados econômicos, embora freqüentemente demonstrem grandes diferenças. Uma idéia de ambas as similaridades e diferenças pode ser vista pelo exame do papel do dinheiro nos sistemas econômicos - pois, mais do que qualquer outra diferença particular, é a ausência de dinheiro que separa as trocas não-econômicas das econômicas" (Coleman, 1990:119, tradução do autor)

Ou seja, a separação entre os sistemas social e econômico se dá pela mera ausência de um meio objetivo. Essencialmente, esta citação revela a concepção social adotada pela teoria da escolha racional. A teoria 
articula o tema da escassez, fato natural que obrigaria os indivíduos a se relacionarem uns com os outros e a gerarem a sociedade, com a temática da troca, que constitui o mecanismo central de interação. O sistema social é visto como um sistema de trocas, de modo que as normas e os valores se tornam contingentes às preferências individuais. As práticas instrumentais constituem os microfundamentos dessa teoria sociológica, que se contrapõe às perspectivas que não ressaltam os interesses autônomos dos indivíduos em todas as situações. Por sua vez, a estrutura não é uma dimensão própria da vida social, mas uma necessidade construída intencionalmente, a posteriori, pelos interesses dos agentes. As normas e regras nascem do conflito e da escassez e criam condições para o advento de equilíbrios. Nesse sentido, Russell Hardin (1995:26-27) indica a necessidade de estudar não apenas os contextos do que denomina "cooperação" - que representam o modelo ordinário de trocas de bens - mas também a "coordenação" que é regulamentada por normas sociais e que condiz com situações em que uma parte da interação maximiza algo somente se as outras também maximizarem. O importante é assinalar que as estratégias elaboradas pelos indivíduos normalmente se baseiam em convenções que, por sua vez, objetivam a promoção de mais transações. Por conseguinte, a escassez pode ser em grande parte mitigada, se relacionada com um contexto que regulamente de forma eficaz o livre intercâmbio. O entendimento sociológico é, portanto, claramente funcional e circular: a lógica da ação coletiva e o oportunismo dos indivíduos acarretam problemas de interação que devem ser resolvidos por instâncias e normas abrangentes.

As regras sociais vinculam-se a uma agência individual anterior às suas próprias regulamentações. Comumente, a idéia de norma na teoria sociológica da escolha racional baseia-se na concepção de informação. É esta categoria que reitera a perspectiva de um controle dos fatos sociais pela cognição individual, pois há o pressuposto de que as regras sociais são instrumentos informacionais que objetivam dar previsibilidade aos agentes inscritos nos espaços de troca. Logo, as normas são princípios que regulamentam e informam as interações, tornando-as mais ou menos previsíveis, mas que, por outro lado, podem ser manipuladas pela orientação instrumental de uma das partes. Segundo Elster (1983:16), a questão da ação social refere-se exatamente à relação eficiente entre as crenças e as evidências disponíveis para um indivíduo. A noção de "juízo" afirma a possibilidade de os agentes alcançarem uma "crença verdadeira", baseada no controle total das informa- 
ções ou das normas de um contexto social. O problema é que a busca de informação seria limitada pela própria racionalidade, devido aos custos de aquisição de novas formas de conhecimento da realidade (Hardin, 1995:15) ${ }^{1}$.

O ponto fundamental dessa perspectiva sociológica é que as normas são sempre circunstanciais e não adquirem um estatuto social autônomo, na medida em que só são "usadas" se estiverem de acordo com a aquisição estratégica de bens ou serviços. Uma das conseqüências de tal compreensão é ver as normas como "limites" às ações. Desconectadas de uma dimensão prescritiva, elas são concebidas como instâncias de decisões individuais, relacionadas com os cálculos de custos e benefícios pessoais. Reitera-se o entendimento de que as normas e os valores se constituem de modo aistórico e contingente. Na verdade, o valor dos fatos sociais pode ser percebido no espaço econômico, ou seja, no valor de troca que possuem. Normas sociais e preços igualam-se, pois as primeiras passam a depender, necessariamente, do interesse de diversos agentes.

Cabe notar que essa perspectiva opõe-se às teorias clássicas da sociologia que indicam uma relação complexa entre os domínios da estrutura social e da agência individual. Conseqüentemente, uma série de dados sociais é descaracterizada e tornada irrelevante, principalmente as relações de condicionamento entre a cultura e as normas e a explicação das diferenças entre as sociedades. Tais questões são deixadas de lado em prol de um entendimento que homogeneíza as esferas sociais e vê a sociedade como uma agregação de trocas independentes. Desse modo, a explicação da coordenação dos agentes a partir das normas ou convenções torna-se vazia. Como afirma Hardin, a coordenação "pode somente ocorrer. E se ela ocorre da mesma forma algumas vezes, o resultado pode ser uma convenção vigorosa que governa, então, comportamentos futuros na medida em que dá incentivos específicos para agir" (idem:45, tradução do autor). O ponto primordial das relações sociais é um indivíduo isolado, livre de imperativos, e a estrutura é examinada como um resultado da volição constante advinda do interesse próprio. Em vez de ser um componente determinante da constituição dos indivíduos, a estrutura social aparece como um fato controlado, formada pelas contingências de subornos, ameaças e promessas, sendo potencialmente não cumprida se contrária às condições impostas pela conduta instrumental. 
As singularidades da teoria social da escolha racional podem ser percebidas no problema exposto por Parsons sobre a possibilidade da constituição de uma ordem social pautada por condutas instrumentais. Parsons (1968:89-94) chama atenção para os limites empíricos da perspectiva de pensar a integração social a partir das atitudes de maximização de meios e fins pessoais. Segundo o autor, tal ideal implica ou a própria desorganização social, dado que os indivíduos buscarão utilizar os outros como meios para seus objetivos particulares, criando assim o caos social, ou soluções metafísicas, como exposto no contrato social fictício de Hobbes e no otimismo liberal de uma identidade natural dos interesses. Nesse sentido, uma perspectiva sociológica que enfatiza o comportamento instrumental, tal qual a da escolha racional, não expressaria de forma adequada os elementos normativos da ação que, afinal, dão sustentação a uma integração social e condicionam as escolhas e decisões individuais. Tais problemas assinalados por Parsons, que na verdade refletem alguns pressupostos centrais da tradição sociológica, não impediram o desenvolvimento da escolha racional na direção de buscar fundamentar uma teoria social, e a possibilidade de uma ordem, mediante a conduta utilitária. Contudo, como veremos, muitas vezes a teoria revela dificuldades nos exames de grupos ou realidades sociais mais complexas, e geralmente parece não criar um argumento consistente sobre o papel da estrutura social perante a atitude instrumental.

O objetivo aqui definido é delinear alguns problemas dessa teoria social, o que implica delimitar a análise em torno dos novos e peculiares entendimentos da escolha racional acerca das normas sociais. Assim, não se intenta tratar dos fundamentos ontológicos e perspectivas já clássicas da tradição teórica que parte da concepção de racionalidade instrumental, a respeito da qual já existe vasta literatura, sobretudo no campo da teoria política. Para considerar as singularidades da sociologia da escolha racional, exponho a seguir as questões da confiança e da disponibilidade de informações para os agentes, que refletem alguns de seus temas medulares. A temática da confiança indica a funcionalidade de certos arranjos sociais, geralmente de tamanhos reduzidos, na resolução dos problemas de ação coletiva advindos do comportamento instrumental. Posteriormente, demonstro que esse tipo de confiança está distante de representar o caráter normativo de uma crença social. Procuro indicar, contudo, que os problemas mais evidentes da teoria surgem quando tenta explicar a viabilidade da confiança e das normas sociais em contextos sociais mais amplos, já que não consegue expor de 
forma coerente as relações entre a agência individual e a estrutura social. Lanço mão, então, do debate presente nas últimas obras do sociólogo Raymond Boudon, demonstrando diferenças entre uma ontologia das ciências sociais e a ontologia econômica que fundamenta as análises da escolha racional. Por fim, articulando críticas à concepção de racionalidade instrumental expressa por alguns autores que não pertencem ao campo da teoria da escolha racional, argumento que não parece sociologicamente consistente avaliar as normas e as condutas sociais pelo fato de maximizarem necessidades, interesses e vantagens pessoais. Sugiro que é a caracterização dessas mesmas necessidades e interesses que precisa ser explicada em sua gênese, o que só pode ser feito com a análise da especificidade do comportamento instrumental na modernidade.

\section{O CÁLCULO DA CONFIANÇA E A EVOLUÇÃO DA COOPERAÇÃO}

Na medida em que se pressupõe um sistema baseado em relações imprevisíveis de competição, a confiança surge como um parâmetro que indica a funcionalidade de certos ambientes na resolução dos problemas de ação coletiva. O crédito nos outros é analisado a partir de sua potencialidade em permitir intercâmbios previsíveis em contextos egoístas. Nesse caso, a questão sociológica é saber quando um agente deve cooperar e em que condições ele deve seguir seus interesses nas relações sociais (Axelrod, 1984:vii) ${ }^{2}$.

A confiança articula-se ao tema do risco a que os indivíduos se expõem em suas transações. O risco pressupõe o tempo que as trocas levam para se concluírem, o que implica incerteza para o agente que investe uma soma de recursos antes de receber um retorno. A teoria da escolha racional afirma que, em espaços sociais de tamanhos restritos, a incerteza pode ser mitigada de duas maneiras. A primeira aponta para a criação de mecanismos formalizados por contratos e sistemas legais. Todavia, o que interessa à sociologia da escolha racional é a segunda forma, baseada em fatores de confiança que estimulam o intercâmbio de baixo risco de um modo informal. Esses fatores manifestam e proporcionam um ambiente previsível que prescinde dos custos de organização de um sistema legal ou contratual. Cabe notar, porém, que a perspectiva sociológica da escolha racional estabelece a união entre a idéia de uma dimensão social que se impõe sobre as preferências pessoais e um cálculo de custo e benefício que os agentes elaboram autonomamente. Assim, a confiança e o risco são vistos como fenômenos parale- 
los, pois ainda que princípios sociais possam adquirir alguma independência em relação à contingência das transações, eles também podem ser instrumentalizados pelos interesses pessoais. A confiança é subordinada a uma espécie de aposta individual, calculada matematicamente nos mínimos detalhes, na medida em que

"[...] o ator sabe o quanto pode ser perdido, o tamanho da aposta, o quanto pode ser ganho (a quantia que pode ser ganha) e as chances de ganhar. Estes e somente estes são os elementos relevantes [...] Essa expressão simples é baseada no postulado de maximização da utilidade sob risco. O credor (trustor) potencial deve decidir entre não depositar confiança, no caso de não haver mudança em sua utilidade, e depositar confiança, no caso de sua utilidade esperada relativa a seu status presente corresponder ao ganho potencial vezes a chance de ganho menos a perda em potencial vezes a chance de perda" (Coleman, 1990:99, tradução do autor)

Nesse sentido, não há na norma da confiança um aspecto de prescrição comportamental. As relações sociais são submetidas a um cálculo sobre os benefícios e custos de cooperar ou não, de forma que o credor (trustor) deve possuir mecanismos hábeis para dissuadir a outra parte de tomar o caminho do rompimento dos acordos. Por conseguinte, o cumprimento das promessas estaria vinculado ao advento de trocas freqüentes entre os mesmos indivíduos. Esta seria uma característica natural das relações sociais, pois agentes racionais procuram interagir com as mesmas pessoas. O principal incentivo para o cumprimento dos acordos é que o parceiro da interação presente deverá ser útil em um empreendimento futuro. As transações tendem a se constituir, então, como jogos repetidos, de modo que todos os agentes envolvidos possuem um interesse recíproco em reiterar promessas feitas. O "recebedor" (trustee) de um benefício espera perder muito se a relação que estabelece tem continuidade temporal, ao contrário de uma transação ou "jogada" simples e contingente com sujeitos desconhecidos. A informação ganha status especial nessa perspectiva, pois existe uma correlação direta entre os atos de um indivíduo e a próxima jogada a ser elaborada por outro agente (Smith, 1982:149). Já que as relações sociais tomam a forma de situações de risco, são as informações que precisam a possibilidade de um contexto de confiança mínima. Paralelamente, quanto mais as informações a respeito das jogadas estabelecidas forem difundidas por meio de uma estrutura comunicativa, maior será a confiança inscrita nas interações. 
Na medida em que os jogos são repetidos, torna-se possível guiar as expectativas e estabelecer punições de acordo com as ações passadas. Além disso, entra no quadro do jogo a questão das reputações (Axelrod, 1984; Heap e Varoufakis, 1995:167-194). O ponto fundamental é que a repetição possibilita o desenvolvimento de cooperações sem a necessidade de agências externas para as estimularem. O dilema do prisioneiro tende a ser resolvido, e a possibilidade de jogadas cooperativas voltadas para ganhos mútuos não é mais vista como irracional. Os jogadores podem adotar a estratégia do tit for tat - repetição da jogada anterior do adversário, de forma a ameaçá-lo com defecção se ele tender a fazer o mesmo - para resolver o jogo satisfatoriamente. Denomina-se essa perspectiva como "evolucionária", dado o pressuposto de que a cooperação e a reciprocidade de comportamentos advêm de forma espontânea, mesmo em um ambiente composto de indivíduos egoístas (Axelrod, 1984:viii). Portanto, além de sua composição espacial, um aspecto central da cooperação é a dimensão temporal. O cálculo efetuado pelos agentes indica a razão entre os ganhos imediatos de uma conduta oportunista em relação à cooperação baseada em uma rede evolutiva mais ou menos estável de ganhos futuros, ainda que não tão certos quanto os benefícios presentes.

Cabe notar que o entendimento das teorias dos jogos repetidos e evolucionária parte do grau zero de uma sociedade sem normas sociais. A questão essencial diz respeito ao surgimento da cooperação em um mundo povoado de pessoas egoístas e sem autoridade central (idem:3). Supõe-se que uma moralidade, no sentido ordinário, não é importante, dado que nada mais é demandado nas interações além do interesse próprio dos agentes. Portanto, valoriza-se a esfera das informações, em detrimento das regras ou convenções sociais. Quando os autores manifestam uma concepção de cultura para o estudo da cooperação, sugere-se um modelo muito simplificado, em que os indivíduos adquirem seus comportamentos através da imitação de atores exitosos, o que compõe uma "evolução estabilizada" (Smith, 1982:172, tradução do autor).

O que parece fundamental é que, mesmo certa desconfiança sendo inevitável, ela pode ser parcialmente contida pela sistematização de informações sobre as partes envolvidas nas interações. Assim, resolve-se parte do problema, apontado por Anatol Rapoport (1980:178-179), das teorias dos jogos que descartam a importância dos atos comunicativos e das crenças individuais, de modo que uma esfera de informação e co- 
municação social passa a ser fundamental para as análises das trocas sociais ${ }^{3}$. A importância das informações para deter os comportamentos imprevisíveis não se limita às interações impessoais, mas é pressuposta mesmo nas esferas privadas da família ou das relações amorosas. Segundo Coleman, "é principalmente por essa razão que pais de estudantes de high school querem conhecer e saber o tanto quanto possível sobre os garotos com os quais suas filhas saem" (1990:103, tradução do autor). É interessante destacar este exemplo banal, pois ele explicita claramente a formulação sociológica a respeito da relação entre confiança, risco e normas sociais. A conduta dos pais e dos garotos em relação às meninas é comparada aos cálculos elaborados, por exemplo, nos intercâmbios entre exportadores e seus futuros importadores. Os garotos procedem ao cálculo sobre as perdas e ganhos da agressão sexual das meninas, que seria, segundo Coleman, a atitude mais desejada se não estivesse inserida em uma relação de reciprocidade estratégica. Por sua vez, as meninas partem do fato de que "o ganho consiste na atenção do garoto e em estar habilitada a sair em encontros futuros, em vez de ficar em casa tal como no passado" (idem:102, tradução do autor). No mesmo sentido, a construção de laços de amizade expressaria a expectativa, em parte instável, de se depositar confiança em certos indivíduos e não em outros, estabelecendo transações baseadas no interesse próprio. O rompimento ou a transgressão de uma amizade, por exemplo, não se vinculam a certos deveres socialmente compartilhados, mas a uma avaliação pessoal que indica que

“[...] um ganho potencial a partir de uma relação íntima também pode ser grande, mas, desde que existam muitos outros amigos potenciais que podem prover um ganho equivalente aproximado, a comparação relevante não é entre a perda potencial absoluta e o ganho potencial absoluto, mas entre a perda potencial absoluta (tal como a violação da confiança de alguém ou o abuso do corpo de alguém) e a diferença entre o ganho esperado deste amigo e o ganho esperado de outro" (idem:104-105, tradução do autor, ênfase no original)

O radicalismo de tais proposições faz transparecer a contingência da confiança e das normas sociais, que aparecem como fatores a serem usados ou descartados, dependendo das circunstâncias diversas dos interesses pessoais. A concepção de racionalidade instrumental é levada nestes exemplos a situações-limites, tendo-se em conta a fonte expressiva que as dimensões do amor ou da amizade possuem, por intermédio de complexos esquemas normativos, nas sociedades modernas. 
Contudo, a teoria não responde de maneira satisfatória à questão lógica de como os atores podem gerar relacionamentos intensos e sair facilmente da situação do dilema do prisioneiro se eles não confiam verdadeiramente em seus semelhantes. Por outro lado, cabe questionar se a confiança, nas análises da escolha racional, adquire um estatuto de norma social, dado que não há nenhuma referência a uma esfera prescritiva inquestionável. O que se verifica é a centralidade da concepção de "depósito de confiança" (placement of trust) (idem:97, tradução do autor). Ou seja, a confiança não se caracteriza por uma dimensão estruturante, independente das trocas efetuadas, mas sim como o resultado da matemática instrumental de uma situação particular. Desse modo, certos autores indicam a necessidade de as relações sociais, principalmente em contextos impessoais, estarem patrocinadas por mecanismos formais ou contratos ordinários, garantidos pelo aparelho estatal (idem:98; Hardin, 1988:46-47).

Fundamentalmente, as proposições sociológicas da escolha racional sugerem a irrelevância da dimensão estrutural e cultural para a explicação das relações sociais. Por sua vez, como veremos a seguir, os problemas mais patentes da teoria se evidenciam quando ela sai da esfera de contextos de interação de tamanho reduzido e tenta explicar a viabilidade da confiança e das normas em grandes comunidades. Demonstrando indecisão analítica entre as esferas do cálculo individual e da estrutura social, a teoria parece incapaz de explicar eventos que comportam múltiplos agentes. Ela permanece indecisa, sobretudo, entre proposições que afirmam a existência autônoma das normas e outras que indicam a necessidade inexorável de sanções para a manifestação de orientações não-egoístas.

\section{NORMAS E AUTONOMIA INDIVIDUAL EM SOCIEDADES COMPLEXAS: PROBLEMAS TEÓRICOS}

Saindo da esfera de troca direta de um grupo limitado de indivíduos, ou do que podemos denominar microssociologia, parte da literatura da escolha racional também procura explicar a emergência de normas em contextos sociais abrangentes. As análises demonstram uma preocupação mais vasta em compreender os fenômenos coletivos, principalmente os vinculados a um espaço caracterizado por transações dispersas e impessoais. Os trabalhos procuram, sobretudo, conceber a produção de normas sociais funcionalmente adequadas aos problemas 
provenientes da interação estratégica, o que pode gerar um funcionamento mais apropriado do contexto socioeconômico.

Parte da teoria sociológica da escolha racional afirma a centralidade das "externalidades" como parâmetro essencial para o exame da interdependência social em ambientes complexos (Coleman, 1990:20-21; Opp, 2001:15-16). A existência de problemas voltados para atores externos a uma transação, sobre a qual não possuem controle direto, origina uma preocupação singular e funcional em relação às normas sociais. Existiriam dois tipos de externalidade: a "positiva", quando uma ação beneficia outros indivíduos situados fora do processo de transação; e a "negativa", quando uma ação acarreta conseqüências maléficas aos agentes. Para os autores da escolha racional, são estas últimas que geram um interesse mais efetivo, pois as pesquisas podem motivar o impedimento de certas ações que causam prejuízos coletivos.

Uma das formas de deter as externalidades negativas seria instituir um sistema de compensações aos indivíduos afetados por certas ações, produzindo uma espécie de "mercado de externalidades". Assim, os agentes interessados na consecução de ações que provocam danos estabelecem contatos diretos com os afetados a fim de comprarem direitos de efetuarem tais ações. Uma estrutura social é gerada, então, no momento em que os indivíduos concedem a outros direitos de controle sobre certas práticas, o que gera benefícios a todas as partes envolvidas no processo. Segundo Coleman (1990:145), é a fundação dessa relação que cria a transição do plano micro para uma dimensão efetivamente social. Para tal contexto ser passível de previsão, as normas aparecem como mecanismos que direcionam as atitudes em certo sentido. Cabe notar que a direção das ações não precisa ser definida legalmente, pois pode ser ocasionada por uma situação de troca informal e voluntária entre os interesses envolvidos. Contudo, como certos autores do próprio campo da escolha racional chamam atenção, um mercado de externalidades está fora de questão em sociedades de grande porte, devido à impossibilidade de estabelecimento de acordos entre uma vasta gama de agentes. Em tais contextos, os indivíduos que impõem as externalidades se encontram distantes das pessoas que as sofrem. A gênese das normas sociais deve se encontrar, então, em outros mecanismos de controle sobre as ações que causam danos coletivos.

Tal como nas circunstâncias em que o problema das externalidades se impõe, a teoria sociológica da escolha racional reivindica uma "propo- 
sição instrumental" (Opp, 2001:15, tradução do autor), pois as normas sociais devem surgir como ferramentas para a obtenção de objetivos coletivos. Para além das condições que geram externalidades, as normas da estrutura social aparecem como mecanismos para resolver situações compostas pelo dilema do prisioneiro e que necessitam de coordenação para a realização de um equilíbrio mais proveitoso. Assim, situações sociais melhores podem ser obtidas por intermédio de um acordo explícito ou tácito, no caso dos problemas de coordenação, ou por meio de sanções que façam os indivíduos cumprirem as promessas efetuadas em situações caracterizadas como dilemas do prisioneiro. Pode-se dizer que há um "uso utilitário" das normas, na medida em que os sujeitos levam vantagem agindo de acordo com elas. Desse modo, "o prêmio da conformidade em relação a uma regularidade consiste, então, no ato mesmo da conformidade, visto que isto garante o que é desejado por todos - a realização de um equilíbrio coordenado" (Ullmann-Margalit, 1977:85, tradução do autor).

Coleman (1990:253) indica a diferença dessa concepção social em relação ao ambiente isento de normas definido pelo modelo tradicional do dilema do prisioneiro. Enquanto neste a capacidade de instituir uma cooperação previsível é excluída, pois os agentes não podem se comunicar (e mesmo se o fizessem não poderiam confiar uns nos outros), sua perspectiva pressupõe um contexto de livre comunicação, o que envolve a possibilidade de formação de regras que se façam cumprir por si mesmas. O exame das normas sociais torna-se relevante nos contextos paradoxais em que a teoria dos jogos é indiferente entre as soluções apresentadas ou nos casos em que o resultado é subótimo e socialmente inaceitável (Ullmann-Margalit, 1977:15). Nesse sentido,

“[...] quando um grande grupo ou sociedade encara um problema de coordenação, eles podem não estar aptos a basear sua coordenação em uma promessa. Porém, como Hume argumenta, eles podem resolver prontamente seus problemas por intermédio da convenção. Se o problema repete-se muitas vezes, qualquer coordenação exitosa pode assinalar como se coordenar novamente na próxima ocorrência do problema. A estratégia à qual o grupo recorre pode se tornar uma convenção, no sentido de que é a escolha óbvia de praticamente todos sempre que o problema padrão ocorre" (Hardin, 1988:49, tradução do autor).

Todavia, não se explica satisfatoriamente nessas análises que mecanismos sociais específicos impediriam o advento do comportamento oportunista, ou seja, falta uma explicação da resolução do próprio dile- 
ma do prisioneiro. A questão é como proteger um contexto de benefícios coletivos que é instável devido às tentações dos participantes envolvidos. Os princípios da racionalidade individual chocam-se claramente com as proposições sociais, configurando-se uma contradição que os autores parecem incapazes de resolver. O problema é que ao pressuposto de que os agentes buscam minimizar os riscos e a falta de previsibilidade das interações é adicionada a idéia de que eles determinam espontaneamente o meio social mais eficiente para o alcance de tal objetivo. A questão sociológica a ser enfrentada é, portanto, a explicação da maneira pela qual esse meio é escolhido, pois isto depende de uma teoria que observe os quadros cognitivos e sociais dos indivíduos, ou seja, de um exame bem mais amplo que o modelo de racionalidade da escolha racional.

Devido à possibilidade do comportamento oportunista - principalmente nas situações em que há um elemento de renúncia individual em relação a alternativas mais vantajosas -, a maior parte das análises considera as normas sociais como dependentes de sanções específicas, condizendo com a necessidade de controle para que os indivíduos não ajam somente a partir de seus interesses. A temática das sanções procura unificar racionalidade e normas sociais, demonstrando que as ações desviantes podem afetar diretamente as utilidades pessoais. Assim, as normas só podem se institucionalizar por meio da vigilância, de forma que aqueles que não participam da ação coletiva passam a ser vistos como perdedores ou exploradores (Wolfelsperger, 2001:85). É o desejo de não ser explorado que estabelece uma ligação entre a sanção social e o valor dos elementos ao nível racional das preferências pessoais em jogo. Prêmios e punições tornam-se mecanismos essenciais nesse modelo de sociedade, em que interesses e normas se relacionam de forma instável.

Entretanto, as questões tornam-se mais complexas nos contextos em que o estabelecimento de sanções produz tanto beneficiários quanto perdedores, que deixam de usufruir o direito de realizar ações mais vantajosas. Já que não há como instituir um sistema de vigilância uniforme ou completo, não se explica o porquê de os agentes aceitarem perdas pessoais em prol de um bem-estar geral, mas abstrato. Por outro lado, é fundamental notar o problema substantivo da temática das sanções em relação à concepção de eficiência definida nos parâmetros da otimização paretiana, pois uma das partes de uma transação pode perder algo. Para tentar evitar certas contradições, Ullmann-Margalit (1977:117) faz so- 
mente vagas referências a respeito de sanções internas em relação ao não-cumprimento das normas sociais, como sentimentos pessoais de culpa, remorso e vergonha. Já Coleman (1990:260-262) indica a inevitabilidade de perdas individuais, o que define uma situação subótima contrária a seus pressupostos. Deve-se notar, além disso, que o âmbito das normas sociais pressupõe, necessariamente, uma dimensão de poder, o que desqualifica a suposição de uma distribuição igualitária e consensual de direitos entre os indivíduos. Assim, normas e sanções tornam-se mais fracas se contrariam os interesses de agentes detentores de mais recursos. Ainda que Coleman (idem:270) atente para o fato de que o impedimento das externalidades depende do conjunto de recursos de poder que os indivíduos possuem, o próprio autor pouco desenvolve esta questão, preferindo notar a capacidade de os agentes estabelecerem sanções a partir de canais de comunicação dispersos e a possibilidade de sistematização geral de relações de confiança.

Esses problemas refletem a falta de resolução da teoria sociológica da escolha racional em geral do dilema entre a noção de oportunismo e um comportamento submetido às normas sociais. As análises geralmente limitam-se a notar que as normas se constituem, por vezes, como fatores de "segunda ordem", que são instrumentais para impedir certas condutas na tentativa de gerar bens públicos de primeira ordem (Opp, 2001:15-16). Assim, o entendimento de eficiência e bem-estar geral torna-se problemático, pois a teoria afirma, contraditoriamente, a autonomia da busca do interesse próprio ao mesmo tempo em que supõe processos de socialização que enfraquecem a sua concepção de ação. Além disso, não se explicita por que indivíduos racionais, com seus problemas de ação coletiva, se uniriam em ambientes impessoais a fim de superar certas externalidades ou ocasionar um resultado socialmente benéfico.

Um dos problemas centrais das análises da escolha racional é que elas deslizam para explicações tautológicas. Na tentativa de considerar as fontes de coordenação social - a língua, a religião, a comunidade e os costumes locais, por exemplo - como fatores de interesses pessoais, os autores passam a admitir eventos que descaracterizam o conceito de ação racional. Os valores ou crenças não são definidos como arcabouços discursivos que constituem em grande parte a realidade social, mas limitam-se a instrumentos contingentes a serem usados na maximização de interesses exclusivistas. Ainda que os trabalhos admitam que muitas propriedades da cultura se produzem coletivamente, eles procuram ar- 
gumentar que o gozo e os benefícios desses aspectos sempre se vinculam a uma dimensão de consumo racional de certos agentes (Hardin, 1995:68). Ora, nesta lógica, claramente circular, qualquer comportamento social pode ser descrito como racional, simplesmente porque o indivíduo assim quer e age. Por conseguinte, nos momentos em que a teoria concede a existência de condutas normativas que não indicam nenhuma referência instrumental, a tendência é chamá-las de irracionais ou inseri-las na idéia de maximização de conforto epistemológico (idem:61-63; 139), de modo que qualquer prática se torna interessada. A conclusão padrão limita-se a afirmar que as normas sociais tendem a ser mais fortes quando servem a certas preferências pessoais.

Fundamentalmente, não se explica satisfatoriamente a forma pela qual uma conjuntura de coordenação social abrangente se constitui. Além disso, elimina-se a questão das diferenças de uma comunidade para outra, pois se supõe que todas estão subordinadas ao mesmo tipo de comportamento instrumental. Também fica aquém de uma compreensão consistente a manifestação de grupos que provêm poucos benefícios a seus membros, como comunidades religiosas periféricas, identidades étnicas marginais sem expectativa de desenvolvimento ou até agremiações esportivas fracassadas. É interessante notar que, enquanto as proposições teóricas sobre o nível "macro" se condicionam pelo desenrolar do "jogo social", nunca se questiona a dimensão "micro" na teoria social da escolha racional. Esta última é sempre qualificada por meio da idéia de uma natureza que não é passível de ser nem modificada nem desenvolvida pelos intercâmbios que os agentes efetuam.

Cabe notar ainda como a teoria sociológica da escolha racional examina as normas e valores sociais que, a princípio, não apresentam funcionalidade específica. Nesse caso, a tendência da teoria é enfatizar a direção social imprevisível e casual dos comportamentos racionais. Por meio de um processo simples e imponderável, certas normas surgem quando atores que possuem interesses similares geram, a partir de suas ações descoordenadas mas regulares, o advento de uma regra. A norma social aparece, portanto, como um resultado agregado não esperado (Opp, 2001:23-26). Um exemplo desse tipo de entendimento pode ser dado pela mutilação genital feminina:

"[...] eu ilustrarei o modelo de emergência de normas não planejadas com a explicação de Mackie (1996) da mutilação genital feminina. Suas asserções básicas podem ser resumidas como: (1) tanto os homens quanto as mulheres 'desejam fortemente criar com êxito suas crianças 
biológicas' (p. 1.007); (2) os homens têm interesse em controlar o comportamento sexual das mulheres de modo a assegurar que elas não criem descendentes de outros homens; (3) em sociedades poligâmicas com alta desigualdade de recursos, os custos de monitoramento são altos para os homens que possuem várias mulheres; (4) os pais e as mulheres têm interesse que as filhas se casem com homens ricos; (5) a mutilação feminina serve a este interesse: ela é um sinal de fidelidade e impede a promiscuidade sexual; (6) mulheres circuncidadas são preferíveis pelos homens como esposas" (idem:27, tradução do autor).

Este exemplo expõe as questões estruturais que a teoria não responde. A primeira refere-se à explicação do surgimento do fato social específico da circuncisão, e não de outros mecanismos de "monitoramento". Outra questão sociológica que não se examina é a maneira pela qual a submissão da mulher, que sofre corporalmente a violência, se constitui como um interesse próprio dos homens. Também não são explicados fatos que parecem surgir exclusivamente da estrutura social, como o de que "homens têm interesse em controlar o comportamento sexual das mulheres", ou "pais e mulheres têm interesse que as filhas se casem com homens ricos". Estes fatos e valores não são naturais, outras sociedades não os valorizam. O que parece é que o autor usa, de forma etnocêntrica, traços culturais relevantes de sua própria sociedade para compor explicações ad hoc. Todavia, é a própria caracterização desses traços, que os agentes internalizam e variam de sociedade para sociedade, que precisa ser explicada em sua gênese e particularidade.

Importa notar que nenhuma referência histórica é mencionada pela teoria, mesmo se as condutas possuem um aspecto tradicional que os indivíduos não questionam. Dimensões prescritivas tais quais o sistema de castas na Índia, a repreensão por sujar as ruas em uma grande cidade, as restrições a manter relações sexuais antes do casamento em comunidades religiosas são vistas como exemplos de resultados de trocas consensuais, e não como modelos culturais que exercem alguma forma autônoma de condicionamento social. Na busca de entender comportamentos que não se vinculam ao conceito de racionalidade instrumental - tais como ações fortemente emotivas em seguir um líder; uma greve de fome por interesses abstratos e longínquos; a expectativa em assumir uma posição na linha de frente de uma guerra; terroristas que explodem a si mesmos com bombas -, Coleman (1990:273-282) aponta para certas satisfações pessoais baseadas nos incentivos e prêmios resultantes da união de indivíduos que procuram 
um mesmo objetivo. Contudo, não é evidente que indivíduos que seguem um determinado líder sofram encorajamentos de outros indivíduos. Na sociedade moderna, por exemplo, esta ação pode perfeitamente se dar em bases impessoais. No mesmo sentido, o fato de estar em greve de fome para beneficiar terceiros não se relaciona, necessariamente, com prêmios ou incentivos disseminados socialmente. Seria ainda mais complexo tratar tal comportamento como portador de satisfação pessoal, assim como a ida autônoma para a linha de frente de uma guerra. Por outro lado, tratar como racional um conjunto de condutas diversificadas implica análises tautológicas, sendo impossível imaginar que atitude não seria racional. O conceito de racionalidade passa a se relacionar com elementos variados, perdendo a sua capacidade de explicação.

Para tentar solucionar os impasses, alguns autores apontam para a emergência de normas informais que implicam processos de policiamento interno. Segundo Coleman, "é a instalação no indivíduo de algo que pode ser qualificado como uma consciência ou um superego: chamarei a isto de sistema de sanção interno" (idem:294, tradução do autor). Por vezes, o processo de socialização seria tão influente que poderia até mesmo criar um outro self (idem:517-518). Racionalidade e sancionamento interior aparecem, então, como dois mecanismos paralelos. $\mathrm{O}$ agente internalizaria certas regras e normas, sob a forma de restrições ao seu comportamento, e seria capaz de mentir a si mesmo para escapar do caráter de sanção delas. Assim, a satisfação de interesses pode ser alcançada pela transformação da estrutura interior do indivíduo, de forma a adaptá-la aos imperativos do arranjo social exterior. Essa expansão do self une o indivíduo ao seu contexto sem questionar a sua racionalidade. Isto poderia explicar, por exemplo, processos de identificação social tais como orientações individuais que ocasionam benefícios psíquicos gerais, compartilhamento de experiências, mesmo ruins, ou processos de transferência de poder, como a identificação com lideranças políticas ou religiosas.

Freqüentemente, as análises destacam fatos psíquicos que, por sua vez, não são devidamente explicados. Ainda que a negação da cognição instrumental seja possível a partir de processos de socialização, as pesquisas da escolha racional não compreendem tais mecanismos sociais. Por um lado, as normas parecem ser produzidas internamente pelo indivíduo. Por outro, parecem ser estrategicamente estimuladas por certos agentes, como organizações religiosas ou o Estado nacional. Por 
vezes, configura-se a suposição de que os indivíduos possuem duas funções de utilidade, uma baseada no ponto de vista moral e outra fundamentada exclusivamente em sua racionalidade instrumental (Wolfelsperger, 2001:74-75). As questões tornam-se mais complexas mediante a idéia de que as normas gerais de uma sociedade tendem a ser fracas quando são desconectadas de um contexto de interações repetidas e de incentivos pessoais (Hardin, 1995:107). Fundamentalmente, os problemas refletem o fato de que a internalização das normas sociais aparece contraposta à natureza racional dos indivíduos, gerando a concorrência de duas dimensões que, a princípio, são apresentadas como antagônicas no pensamento da escolha racional.

A questão do voto é paradigmática desses problemas, principalmente das relações que a teoria sociológica da escolha racional efetua entre razão instrumental e irracionalidade, ou entre uma agência livre de determinações e um tipo de estruturação social dos comportamentos. $\mathrm{Na}$ verdade, a questão já é automaticamente anexada à expressão "paradoxo do voto". De acordo com as proposições da teoria, um eleitor não tem nenhum benefício em votar, dado o cálculo entre os custos de tempo e esforço da ação e a impossibilidade relativa de seu ato de ir até as urnas influir no resultado final. Mesmo interessado no resultado da eleição, e em seus ganhos pessoais no caso da vitória de um candidato específico, o eleitor racional sabe claramente da incapacidade de seu voto ser decisivo, fato que o dirige para a abstenção. A eleição reflete o problema da ação coletiva de que nenhum cidadão pode ser excluído dos benefícios de um bem público, mesmo que não tenha contribuído para a produção de tal bem. Contudo, a maior parte dos eleitores vota, o que ocasiona o paradoxo. Na medida em que a empiria contradiz as previsões da teoria, essa é uma das questões mais debatidas no campo da escolha racional.

Os trabalhos contêm diferentes suposições sobre o ato de votar. Alguns sustentam que os agentes não julgam corretamente a probabilidade de seu voto influenciar no resultado, tendo uma reflexão que inflaciona a expectativa de suas decisões particulares diante do contexto social. Outras análises recorrem a fatos como o dever cívico, classificados como irracionais. Assim, sugere-se que os agentes vão às urnas quando pensam ter uma obrigação para tal ato ou quando procuram afirmar sua identidade partidária. Algumas pesquisas baseiam-se na utilidade originada da contribuição para um esforço coletivo de sucesso. Por outro lado, há trabalhos que continuam a propor a racionalidade do cál- 
culo do voto, e procuram demonstrar o medo que o indivíduo possui de perder a oportunidade de decidir uma eleição, em caso de um provável empate. Outros se fundamentam na teoria dos jogos e asseveram que, do ponto de vista estratégico, é coerente votar devido à expectativa de que os outros agentes racionais não votarão, o que tornaria um voto pessoal decisivo para o resultado final. Como uma conseqüência não esperada, essas expectativas individuais acabam ocasionando uma ida massiva às urnas.

Contudo, as evidências empíricas não provam tais expectativas, e a tendência dos trabalhos a respeito da conduta eleitoral é transformar os dados e torná-los consistentes com a teoria da escolha racional (Green e Shapiro, 1994:55). As análises limitam-se a concluir, sem explicações consistentes, que o ato de votar é geralmente mais gratificante do que seus custos, sendo, portanto, racional. Todavia, a noção de que a abstenção eleitoral introduz algum tipo de perda pessoal é claramente contraditória com a concepção de racionalidade da teoria, principalmente porque os custos e os benefícios de tal atitude são explícitos para qualquer reflexividade instrumental. De forma geral, esse caráter contraditório parece estar vinculado ao fato de a teoria não fazer referência à estrutura sociopolítica na qual os atores estão inscritos. No caso do voto, por exemplo, a falta de análise estrutural descarta o estudo essencial da modificação circunstancial do comportamento cívico e político de uma eleição para outra, ou em diferentes sociedades.

Deve-se notar que alguns autores assumem conscientemente a direção analítica limitada à dimensão individual e afirmam as vantagens de uma metodologia "positiva" e simples para evidenciar os fenômenos essenciais das ações. A construção teórica procura efetuar certa depuração dos fatos empíricos, interessada mais no que poderia acontecer às situações concretas se guiadas pela racionalidade do que no que realmente ocorre (Ullmann-Margalit, 1977:1-2). O modelo de interação social elaborado por Axelrod (1984:17-18), por exemplo, evita explicitamente certas questões, como o comportamento fundamentado por hábitos ou regras sociais e as escolhas inconscientes ou não-estratégicas. No mesmo sentido, quando procura explicar a gênese das preferências dos agentes, o que poderia gerar um tipo de análise decididamente sociológica, Coleman (1990:515-516) prefere se dirigir para explicações de cunho estritamente psicológico. Já Elster (2000:692) assume os limites da teoria da ação racional e aceita a importância social das condutas quase-racionais ou baseadas em instâncias emocionais 
que se contrapõem ao raciocínio estratégico e instrumental dos agentes. Segundo o autor, a saída é encarar com modéstia a capacidade explicativa do modelo da escolha racional, o que não implica questionar sua qualidade em esclarecer e prever os fatos fundamentais da vida humana.

A ausência de um exame coerente da relação entre a estrutura social e a agência racional resulta na tendência da teoria social da escolha racional em valer-se dos fenômenos que não caibam em seu corpo teórico como ocorrências irracionais ou ininteligíveis. Essa direção analítica lembra a divisão metodológica elaborada por Pareto (1968) entre os comportamentos lógicos e não-lógicos. Assim, pressupõe-se grande parte das ações como fatos que devem ser desconsiderados, na medida em que pertencem a um estágio a ser ultrapassado pela sistematização da racionalidade econômica. Por conseguinte, os autores não atentam para o dado primordial de que a concepção de racionalidade que sustentam depende de paixões e valores específicos formados por mecanismos sociais complexos, o que subverte um modelo que objetifica as orientações instrumentais e solipsistas.

\section{RACIONALIDADE E INDIVIDUALISMO METODOLÓGICO}

O ponto fundamental que parece ausente nas análises da teoria da ação racional é que as decisões individuais incorporam aspectos desligados de situações estratégicas e de interesse pessoal. Aspectos articulados a dimensões sociais que estão, de certa forma, fora do controle dos agentes. As críticas que Raymond Boudon (2002) faz ao paradigma da escolha racional são importantes por evidenciarem essa esfera social. Além disso, suas críticas são fecundas por indicarem as diferenças entre os campos teóricos do individualismo metodológico e da escolha racional que, apesar de serem muitas vezes confundidos, estão, na verdade, limitados por fronteiras que permitem separar a ontologia da teoria econômica de perspectivas sociais identificadas com uma análise mais estrutural.

Cabe notar, a princípio, que o próprio Boudon trata de desvincular a sua teoria do individualismo metodológico de uma apreciação normativa sobre o individualismo moderno, como fazem as análises pautadas pela concepção de racionalidade econômica. Segundo o autor,

“[...] existe entre o individualismo no sentido metodológico e o individualismo no sentido ético ou sociológico a mesma relação que existe 
entre a palavra bad na língua persa e a palavra bad em inglês [...] as duas pronunciam-se exatamente da mesma maneira, mas como pertencem a duas línguas distintas, seus significados são diferentes. No mesmo sentido, a noção de individualismo possui um significado inteiramente diferente se aparece no contexto da sociologia, no da ética ou naquele da teoria do conhecimento" (Boudon, 1991:46, tradução e ênfases do autor)

Pode-se dizer que o individualismo metodológico expressa uma orientação epistemológica que procura não fundamentar um posicionamento ontológico. Na explicação de um fenômeno social, Boudon prescreve a necessidade de reconstruir as motivações dos agentes e refletir o fato social em questão como um resultado das ações individuais. A metodologia distingue-se das análises de caráter holista que não observam a relação necessária dos fenômenos coletivos com as razões individuais e tratam certas instituições coletivas, como partidos ou organizações religiosas, como dotados de conhecimento ou vontade própria (idem:50). Assim, o plano metodológico não pressupõe que se analisem as sociedades como conjuntos formados de átomos independentes, mas sim que se entenda a relação entre as atitudes e o espaço social, pois é somente esta relação que possibilita identificar e justificar uma ação como racional.

A fim de expor de forma clara seu questionamento da teoria da escolha racional, e as diferenças desta em relação ao individualismo metodológico, Boudon (2003:19-22) indica a série de postulados que resumem o conjunto epistemológico da primeira vertente: (1) todo fenômeno social é produto de ações, comportamentos e crenças dos indivíduos; (2) toda ação individual pode ser compreendida; (3) fora as ações automáticas (ação orgânica de piscar o olho, por exemplo), supõe-se que as ações ou crenças individuais são produtos de razões; (4) as razões consideradas pelo agente sempre levam em conta as conseqüências das ações; (5) os indivíduos interessam-se exclusivamente ou prioritariamente por seus interesses pessoais; (6) supõe-se que o indivíduo conhece e avalia as vantagens e as desvantagens de uma ação ou crença, escolhendo a que lhe traga mais benefícios. Boudon (idem:49-50) argumenta que a concepção de racionalidade proposta pelo individualismo metodológico se limita às premissas 1, 2 e 3, tendo a teoria da escolha racional adicionado os preceitos 4,5 , e 6 . A não-incorporação dos três últimos postulados pelo individualismo metodológico tem o efeito de dar o estatuto de casos particulares e contingentes às situações em que 
os agentes manifestam um comportamento correspondente a estes preceitos. Ainda que Boudon (idem:37) valorize parte da escolha racional por revelar as razões pelas quais indivíduos possuem alguns tipos de conduta, ele critica o fato de que uma vasta gama de fenômenos sociais deixa de ser explicada pelas suposições instrumentais da teoria. Baseado em seu peculiar modelo de racionalidade, Boudon elabora duas críticas essenciais ao paradigma da escolha racional.

Em primeiro lugar, Boudon (idem:42-43;2002:19-20) afirma a existência de várias situações sociais em que a orientação dos agentes se apóia em crenças não-triviais. $\mathrm{O}$ importante é a percepção de que a adesão pessoal a determinadas crenças manifesta uma conduta de natureza cognitiva. Por conseguinte, o problema da teoria da escolha racional é a sua incapacidade de esclarecer fenômenos em que o comportamento dos atores reflete crenças socialmente coerentes e não conseqüenciais. Boudon (2003:45) dá exemplos de ações que tornam problemática a idéia de uma avaliação calculada e auto-referenciada: o eleitor vota; dois jogadores dividem uma soma de dinheiro em vez de o primeiro pegar mais para si mesmo; indivíduos praticam suicídio. Somente em certas circunstâncias específicas as ações e as crenças estão direcionadas para as conseqüências e para um cálculo de custo e benefício. Boudon (idem:44-45) critica, sobretudo, a maneira pela qual a escolha racional procura explicar os fenômenos que evidenciam essas crenças não-triviais e contrárias à racionalidade econômica. O erro capital é supor que os indivíduos aderem às vezes a uma espécie de falsa consciência, operando no interior de "enquadramentos" que exprimem fatores emocionais inautênticos. Assim, o eleitor que não percebe que seu voto não influi no resultado final se basearia em um enquadramento mental que o faria acreditar no contrário, tendo uma estimação errada de seu comportamento. Segundo Boudon, essas suposições são sempre insatisfatórias, na medida em que sugerem que o indivíduo obedece a forças sociais misteriosas e irracionais que não podem ser explicadas.

A segunda crítica de Boudon refere-se ao fato de que a escolha racional permanece impotente perante os valores sociais que manifestam atitudes e capacidades de justificação que não podem ser relacionadas com condutas egoístas. O autor (idem:46) lembra que todo espectador de Antígona condena Creonte e aprova a protagonista sem hesitação, onde quer que se represente a tragédia de Sófocles. O caráter universal de tal atitude está vinculado ao direito de todos à dignidade ressaltada por Antígona. A atitude diante da peça representa uma série de fenômenos 
em que os agentes avaliam situações nas quais não estão de nenhuma forma implicados. A fraqueza da escolha racional em tais circunstâncias deve-se ao fato de que, ao contrário de um distanciamento, a maior parte das pessoas emite uma opinião forte sobre uma questão que não as envolve diretamente. $\mathrm{O}$ fato exemplar de vários indivíduos, que provavelmente nunca serão condenados pela justiça, possuírem uma tendência normativa em relação à pena de morte demonstra que há várias instâncias de envolvimento pessoal não-interessado que não podem ser explicadas no quadro teórico da racionalidade instrumental. No mesmo sentido, o plagiário provoca sempre um sentimento de repulsão, até quando ele não lesa ninguém em particular e contribui antes à notoriedade do plagiado. $\mathrm{O}$ impostor também é visto negativamente, mesmo se seus atos não comportam qualquer inconveniente, senão para ele próprio. A noção geral do direito do mais forte é chocante e seu exercício, inaceitável. O cidadão comum reprova de maneira veemente a corrupção, ainda que não seja afetado de forma direta, e a mesma atitude de indignação é sentida em países com possibilidades remotas de serem atingidos por níveis elevados de tal comportamento. Fundamentalmente, a percepção sociológica demonstra que, independentemente do contexto social, esses fatos são assuntos graves para os indivíduos e são tratados de forma minuciosa, com despesa pessoal de tempo e informações para que tais ações não voltem a se repetir. $\mathrm{Na}$ medida em que são fenômenos de conseqüências pessoais irrisórias, a desaprovação que recebem só se explica porque contrariam regras fundamentais que são a base de um pacto social.

Portanto, o ponto questionável da escolha racional é a sua limitação analítica à racionalidade instrumental, o que a faz negligenciar a razão cognitiva ou axiológica fundamentada em princípios ou teorias sociais. Segundo Boudon, as razões do agente são de caráter cognitivo quando ele aceita uma teoria ordinária pelo simples fato de que lhe parece justa, mesmo que ela não tenha relação com seus interesses pessoais. Por outro lado, a racionalidade possui uma qualidade axiológica quando o agente obedece normativamente a princípios prescritivos. Boudon procura demonstrar que o individualismo metodológico traduz de forma coerente a racionalidade dos atores como a incorporação, mais ou menos consciente, de crenças e atitudes que apresentam "boas razões" circunstanciais de existência. As instituições ou normas sociais, se estabelecidas consistentemente na realidade, são compreendidas como boas, legítimas e aceitáveis, estando desvinculadas dos interesses diretos dos indivíduos. Assim, 
"[...] muitas discussões seriam, sem dúvida nenhuma, evitadas se nos lembrássemos que crença é somente um substantivo formado a partir de crer, ou racionalidade um substantivo baseado na expressão ter razões de. O verbo tem sobre o substantivo a vantagem de não induzir essas visões substancialistas que levam às perguntas sobre o que é realmente a racionalidade ou o que é realmente uma crença" (idem:36, tradução do autor, ênfases no original).

Nesse sentido, a adesão a uma crença ou a um valor social não se dá a partir do cálculo de custo e benefício voltado para a minimização dos meios e maximização dos objetivos. A incorporação de uma teoria ordinária ou prática pelo sujeito não provém do fato de que estas lhe pareçam comportar certas conseqüências. Na perspectiva do individualismo metodológico, a racionalidade consiste em adotar uma crença que, fundamentada como uma teoria, permite perceber os dados de determinado contexto social de maneira satisfatória, simplesmente porque a crença possui razões coerentes. A ação racional implica assumir um conjunto lógico de proposições, quando não se dispõe de uma teoria alternativa mais aceitável. Boudon lembra que, se tomadas de forma literal pela idéia de uma cognição exclusivamente instrumental, a maior parte das ações normais deveria ser entendida como portadora de resultados absurdos e irracionais. A partir das proposições de racionalidade cognitiva e axiológica, Boudon (1999:131) propõe acabar com as "caixas-pretas" presentes na noção neoclássica de racionalidade, produzindo um exame sociológico que admite a análise de novos dados sociais sem recorrer a referências conceituais apriorísticas. Boudon (2003:57) sugere que o processo do conhecimento ordinário é composto dos mesmos parâmetros de crenças que criam o conhecimento científico. Por conseguinte, o aspecto efetivamente social da racionalidade é que as razões se tornam fortes a partir do momento em que elas também assim se apresentam para os agentes inscritos nos mesmos ambientes sociais, ou "parâmetros contextuais", pois "uma razão, um sistema de razões, somente são identificados como tais se o ator tem a impressão que esta razão ou este sistema são compartilhados com outros" (idem:160, tradução do autor).

A análise de Boudon sobre a teoria da escolha racional parece indicar a diferença efetiva da epistemologia das ciências sociais em relação ao entendimento da economia. Mesmo sendo uma vertente que parte de um método centrado no indivíduo, o individualismo metodológico não descarta uma dimensão social estruturante. Boudon (idem:11) dei- 
xa claro que sua perspectiva não sugere que a socialização, quando entendida como um conjunto de efeitos estruturais sobre o comportamento dos agentes, seja um fator desprovido de interesse sociológico. Pelo contrário, a teoria do individualismo metodológico indica a centralidade da descrição dos modos pelos quais os sujeitos incorporam efeitos sociais. Sem entrar no mérito de suas conclusões ou argumentos específicos, o importante é que a teoria procura examinar como os indivíduos interagem com os condicionantes estruturais, se os admitem, os contrariam ou os reivindicam politicamente. Consistindo no fato central de todo projeto sociológico, a subjetividade se articula com certas determinações estruturais. É essa articulação que permanece ausente na teoria social da escolha racional. Nesta, a subjetividade é determinada a priori e a estrutura é vista como mera agregação de interesses antagônicos. Não há um intercâmbio entre agência e estrutura, o que implica uma objetivação do ambiente circunstancial pautado pelo equilíbrio econômico de mercado.

\section{COMENTÁRIOS FINAIS: AS CONDIÇÕES SOCIAIS DO AGENTE MAXIMIZADOR}

Do ponto de vista sociológico das relações entre indivíduo e estrutura social, o elemento mais questionável da teoria da ação da escolha racional é a sua incapacidade de vincular a manifestação da razão instrumental ao ambiente da modernidade. $\mathrm{O}$ fato de os agentes atuarem de acordo com as suas decisões não significa que eles controlem as condições e o contexto social em que estão inscritos. Como argumenta Marshall Sahlins a respeito do perigo analítico das teorias que não observam a realidade estrutural e simbólica: "a alienação final é um tipo de des-estruturação" (1976:220, tradução do autor). É somente através da condição estrutural que podemos revelar as técnicas e as ações singulares disponíveis para os indivíduos, pois as suas práticas, econômicas ou não, dependem de um sistema cultural propagado por processos difusos ou explícitos. Assim, o que é problemático na teoria da escolha racional é a incompreensão da interdependência entre os fins pessoais e o meio social, o que dá um sentido normativo específico às ações individuais.

A tese de Weber (1996) da articulação entre ética protestante e espírito do capitalismo expressa o tipo de entendimento ausente na teoria da escolha racional. Inscrevendo o comportamento racional em um quadro social determinado, Weber procura demonstrar que tanto os valo- 
res do protestantismo quanto a sua manifestação na ação econômica calculada e frugal pertencem a um nível macrossocial e histórico. Cabe notar que o ponto relevante da análise weberiana não é a discussão da relação histórica entre protestantismo e capitalismo como uma explicação causal real, mas sim a exposição da interdependência entre a atitude instrumental e a orientação por valores, entre a agência e a estrutura social, na medida em que a racionalidade que caracteriza o espírito capitalista reflete, em seu significado particular, valores singulares de uma ética religiosa. Nesse sentido, as ações aparecem estruturadas por uma forma simbólica irredutível ao controle direto dos indivíduos, como demonstra a tese da criação de um arranjo econômico por uma religião que é o seu contrário. A ação não se define por suas conseqüências pessoais, mas por resultados sociais abrangentes formados por processos históricos.

A conceituação weberiana da ação social, que caracteriza outros três tipos de orientação comportamental, além da forma instrumental desenvolvida pelo "espírito capitalista", expressa o problema de restringir a concepção de racionalidade a parâmetros instrumentais. Segundo Weber (1968:24-26), a ação social pode ser caracterizada por quatro tipos de orientação: pela racionalidade por fins; pela racionalidade por valores; pela afetividade; e pela tradição. Assim, mesmo no ambiente social da modernidade, é importante compreender a centralidade da orientação que, em oposição à razão econômica, é determinada por valores ou crenças que não demandam correlação com resultados posteriores. O significado dessa orientação reflete práticas que, condicionadas por algum tipo de dever ou "causa", não pressupõem o cálculo de custos e benefícios dos meios e fins da ação instrumental. O ponto essencial do argumento é seu viés sociológico, que evidencia a relação necessária da formação das preferências pessoais com valores específicos da realidade da qual os indivíduos participam. Inserindo as práticas em um contexto social peculiar, esse tipo de procedimento analítico nota que a racionalidade não é um dado transcendente, podendo se articular a um tipo de reflexão desvinculada do interesse próprio. A análise também identifica a potencialidade de um sistema sociopolítico não-instrumental, criado por uma socialização reflexiva sobre crenças ou normas diversificadas.

Portanto, parece não haver sentido, ao contrário do que propõe a filosofia moral utilitarista em geral, em considerar os fins ou "prazeres" individuais a não ser procurando a lógica social que adquirem. Toda 
prática, incluída a do comportamento racional de maximização, articula-se com uma realidade que escapa parcialmente ao próprio indivíduo. Torna-se necessário examinar os interesses pessoais em uma perspectiva que não os defina a priori, ressaltando os processos interativos e simbólicos criados historicamente que fixam certas "disposições", ou seja, inclinações específicas para a ação ancoradas em normas ou rotinas coletivas provenientes das propriedades de um sistema social (Domingues, 1995:141). A teoria da escolha racional não observa tal configuração social, preferindo explicar a emergência das normas e das atitudes como entes independentes, de modo que não chegam nem mesmo a formar uma estrutura (Cherkaoui, 2003:250-251). Todavia, as normas ou crenças vinculam-se umas às outras, pois somente assim podem manifestar um conjunto coerente de instituições e o funcionamento das sociedades. Como lembra Gellner a respeito dos objetivos individuais,

"[...] se pensarmos o estado de coisas que poderiam satisfazer esses fins em um isolamento completo, como se nada mais existisse no mundo, chegaremos a qualquer coisa de absurdo em si, e ainda mais como objeto de desejo. Ocupar o ponto cardinal de um universo que não contém nada além é qualquer coisa de surrealista, tanto quanto possuir barras de ouro em um mundo, para além disso, vazio" (Gellner, 1991:34, tradução do autor, ênfases no original).

Uma sugestão da dimensão social que chamo atenção é apresentada por Bourdieu (1977). O autor apreende as disposições temporais da racionalidade moderna, examinando a inscrição dos agentes em um sistema que estimula estruturalmente um tipo específico de comportamento. Bourdieu afirma que o ponto central da conduta do homo oeconomicus está em sua percepção do tempo, pólo que determina saberes originais de previsibilidade e cálculo de um futuro imaginário. Logo, a ação instrumental aparece determinada por uma rede simbólica singular, pautada por uma acumulação de bens indiretos que contraria a noção econômica de troca direta de objetos das sociedades pré-capitalistas. A representação social do sistema de bens indiretos fundamenta-se no dinheiro, que, sendo apenas um signo, não é fonte, em si mesmo, de nenhuma satisfação. Seu uso está ligado a um futuro calculado, definido pela disponibilidade de bens propostos pela hierarquia de fins pessoais. Funcionando como mediador universal, o dinheiro condiz com uma nova disposição das relações entre indivíduo e sociedade, satisfa- 
zendo uma compreensão temporal desencantada que não considera o futuro controlado por forças externas às ações individuais.

Bourdieu exemplifica essa tese expondo as diferenças das práticas da racionalidade capitalista diante das condutas tradicionais presentes na sociedade argelina. Assim, o espírito moderno do cálculo contrapõe-se ao sistema cultural baseado na honra. Bourdieu demonstra que o trabalho possui nas comunidades argelinas uma função social que é em grande parte desvinculada de fins econômicos. A atividade laboriosa é valorizada em si mesma, tendo as ocupações um caráter que limita as distinções entre trabalho rentável ou não, trabalho produtivo ou improdutivo. O ponto fundamental é a tese de que a condição racional moderna não é uma "escolha" objetiva, mas um fenômeno histórico complexo. Por outro lado, os agentes modernos não se constituem por meio de uma simples acomodação passiva e forçada a mecanismos econômicos "reais". O movimento histórico apresenta vários processos pelos quais hábitos tradicionais são mantidos paralelamente às disposições capitalistas, o que manifesta uma "transformação criativa" e a interdependência entre os indivíduos e as estruturas socioeconômicas (idem:11-18).

O caráter delimitado das práticas instrumentais pode ser verificado também por sua contraposição às características das reuniões políticas mais importantes da comunidade africana Douala, que transcorrem com o consumo de champanhe, ou ao fato de que trabalhadores da comunidade Kigali juntam suas rendas somente para gastá-las em festas da cerveja (Latouche, 2001:28-29). Em sentido similar, na maior parte das tribos indígenas o trabalho é realizado não apenas como mecanismo racional de garantia de alimentação, mas sobretudo como tempo de atividade religiosa, de festa ou de dança (Castoriadis, 1982:40). O trabalho nesses contextos aparece subordinado a bens simbólicos que não são passíveis de serem quantificados ou calculados. Assim, não há "troca" sem identificação e reconhecimento prévio dos participantes das interações, freqüentemente fundamentadas em laços de parentesco. Longe de serem "irracionais", esses comportamentos refletem dimensões culturais que reforçam a solidariedade, enquanto a acumulação de bens materiais é tida como inócua, implicando incômodos aos indivíduos (Latouche, 2001:19-21). Essas orientações não representam qualquer tipo de ilusão ou mistificação, e sua explicação repousa sobre a razoabilidade que possuem em um contexto. 
Tendo em vista a inserção da noção de racionalidade em um contexto social que lhe dá significação, podem-se questionar os argumentos que objetificam os comportamentos instrumentais. Por outro lado, o tipo de configuração social instrumental explicita as relações nas quais se fundamentam as práticas dos agentes modernos. O contexto da produção, essencial ao campo econômico, assume na modernidade um significado que conduz a experiências singulares, dentre as quais o comportamento maximizador é sua característica medular. É fundamental notar que a ação instrumental e a economia moderna dependem de certas instituições, principalmente da generalização de mercados em que os bens e serviços, incluindo o trabalho e o capital, sejam definidos por preços e pela livre oferta e demanda (Polanyi, 1957:247). Somente neste ambiente adquire relevância a idéia de escassez de meios, no caso representada pelo mecanismo universal e quantificável do dinheiro, que sintetiza todos os fins pessoais.

Portanto, um olhar sociológico que parece mais promissor é entender os interesses dos agentes por meio de rotinas, hábitos e rituais coletivos. A formação das instituições sociais passa a ser vista como um processo complexo, desvinculado dos pressupostos que as consideram resultados de objetivos individuais. Desse modo, as normas sociais refletem um âmbito estruturante, influenciando a identidade e o significado dos indivíduos, assim como suas respectivas atividades. A conseqüência dessa influência é que as instituições por vezes adquirem tal força que passam a ser compreendidas como leis, sejam definidas por regras formais ou por costumes e crenças. Logo, torna-se evidente que a força cultural do comportamento instrumental provém de uma dimensão social que induz e legitima o discurso de um agente naturalmente detentor de direitos fundamentais e competência para efetuar escolhas autônomas.

Esse tipo de análise desloca a racionalidade da esfera individual em direção às regras abrangentes que demonstram que o individualismo moderno possui uma história institucional produzida por teorias que pressupõem a democracia liberal no plano político, o livre mercado no plano econômico e um modelo de self nos campos cultural e religioso (Meyer, 1987). Percebe-se, então, que os sistemas sociais modernos prescrevem, através de elementos econômicos, religiosos e políticos, um suporte para que os seres humanos trabalhem sua subjetividade de forma aparentemente independente. Nesse modelo de análise, o indivíduo não aparece só como sujeito, mas também como objeto do proje- 
to de racionalização que ordena uma subjetividade compulsória composta de um tipo legítimo de vida privada. São estes elementos que dão significado à racionalidade instrumental, enfatizando razões e aspirações particulares, dentre as quais se destacam: que o ator deve encontrar auto-estima em si mesmo, se desvinculando de padrões morais; que deve possuir um senso de eficiência e iniciativa; que deve se relacionar com seu ambiente de forma que sua liberdade e independência sejam preservadas (idem:253).

Logo, as ações humanas exprimem uma subordinação à dimensão social, de modo que a concepção da ação econômica como esfera independente se torna destituída de sentido. Uma maneira de perceber isto é chamar atenção para o "processo de institucionalização do processo econômico" (Polanyi, 1957:249-250, tradução do autor), que encaixa a economia em formas sociais e simbólicas as mais diversas, dependentes do contexto histórico. A questão torna-se mais complexa quando, na modernidade, a prática instrumental passa a adquirir relativa liberdade em relação a outros fenômenos sociais, fato refletido na institucionalização da propriedade privada como mecanismo central de regulação social. Enquanto nas economias pré-modernas as trocas e a circulação de bens materiais são fundamentadas mediante uma complexa classificação, na economia moderna o funcionamento do mercado define modos descentralizados de comportamento (Godelier, 1974:174). Como demonstram os trabalhos clássicos da sociologia, quanto mais a divisão social do trabalho se desenvolve, mais as funções econômicas tendem a assumir preponderância, o que se reflete no paroxismo de uma produção que não é controlada por seus produtores diretos. É somente neste contexto histórico particular, no qual as mercadorias são apropriadas individualmente, que passa a fazer sentido a conduta cultural de maximização e lucro produtivo. Contudo, esse fato deve ser explicado e não reificado em categorias que sugerem uma concepção de natureza humana. Tomar a atividade econômica como um espaço independente e universal implica substituir a ênfase analítica nas relações sociais por uma objetivação da troca material do homem com a natureza. Não é em outro sentido que a tradição da teoria crítica questiona a ação instrumental, que absorveria as características liberalizantes ou "negativas" do pensamento. Como exposto de forma geral nos trabalhos de Adorno, Horkheimer, Marcuse e Habermas, as condutas de maximização tendem a transformar a racionalidade em razão técnica. O resultado é uma reflexão articulada a mecanismos de controle e perpetuação das relações sociais voltadas para a eficiência lucrativa e para 
a padronização monopolista. As concepções dicotômicas "razão crítica" e "razão instrumental", "subjetividade" e "apparatus", "administração" e "pensamento negativo", "mundo da vida" e "sistema", expressam a dialética da racionalização, condizendo com a contradição entre o controle humano da natureza, ou a potencialidade de uma ação autônoma, e a subordinação da condição interna e criativa dos indivíduos.

Por outro lado, deve-se notar que, mesmo com o estímulo da individualização e a relativa independência da ação econômica ocasionados pela condição moderna, não há como determinar as fronteiras da dimensão simbólica, como se fosse possível estabelecer uma diferenciação nítida entre instâncias essenciais e secundárias. Ou seja, uma separação entre a orientação instrumental, verdadeira substância da sociedade, e fenômenos tidos por irracionais e dispensáveis. A "utilidade" que os indivíduos procuram satisfazer em suas ações se relaciona com um código cultural de propriedades concretas que governa tanto a produção quanto a dinâmica dos bens expostos no mercado (Sahlins, 1976:166). Esse código desmistifica a idéia da escolha racional de que a realidade é o resultado agregado de trocas efetuadas por interesses autônomos, em que os preços e a oferta e a demanda são os únicos elementos a estruturar as transações. Ainda que nenhuma sociedade possa viver sem a produção da vida material e a sua própria reprodução, estas não são ditadas por uma lei natural ou racional. Há sempre uma margem de indeterminação em que se situa exatamente o campo da história. O movimento social produz-se a partir de sentidos que manifestam "distinções correlativas ao que vale e ao que não vale (em todos os sentidos da palavra valer, do mais econômico ao mais especulativo), entre o que deve e o que não deve ser feito" (Castoriadis, 1982:176).

Ainda que de maneira diferenciada e original, as decisões individuais e a construção de funções de utilidade no contexto social moderno dependem da significação social do consumo e dos bens expostos no mercado. Essa significação fixa contrastes que representam e legitimam as desigualdades de poder presentes na sociedade. Não existe, portanto, um comportamento instrumental livre, pois mesmo a esfera do consumo, que a teoria da escolha racional procura sistematizar a fim de prever as ações, não aparece como uma opção subjetiva, visto ser um processo estruturado por valores sociais e por um sistema simbólico que determinam atitudes e proíbem certos objetos. Pode-se dizer que a modernidade caracteriza-se por uma nova espécie de totemismo (Sahlins, 
1976:178), composta por um sistema predeterminado de objetos que expressa um discurso de diferenças. A ordem cultural define-se a partir das características diferenciais dos bens ofertados, codificados de forma a determinar o tipo de consumo de cada grupo ou classe.

Desse modo, questiona-se a base do raciocínio da teoria social da escolha racional que indica uma concepção mínima de agência, fundamentada na idéia de uma capacidade independente de produzir decisões. Esse entendimento afirma uma separação entre indivíduo e estrutura que torna limitada a percepção de algo externo à cognição pessoal. Todavia, a teoria deve explicar a existência de organizações que não são redutíveis às práticas individuais e que refletem uma subjetividade composta de vários atores (Hindess, 1988:103-104). Em várias instâncias sociais, como uma corporação produtiva ou o aparelho estatal, por exemplo, não há possibilidade de se entender as decisões por meio de avaliação de objetivos definidos individualmente. Nesses casos, as escolhas são produtos de deliberações tomadas em uma variedade de pontos e os resultados subsistem por si próprios. As escolhas tendem a expressar formas institucionalizadas de avaliação e levantamento de informação, acarretando orientações rotineiras e habituais distanciadas da reflexão instrumental.

Portanto, o que se demonstra mais problemático na sociologia da escolha racional é a suposição de que a ação segue um caminho transparente traçado por objetivos individuais. Em contraposição a esse ideal, sugere-se que os agentes se baseiam normalmente em crenças ou hábitos que se conjugam, de uma maneira específica, com os desejos pessoais e a estrutura social. Assim, os meios de se alcançar uma decisão não devem ser prejulgados, como sugerem os modelos de racionalidade econômica. Mesmo os tipos de questões que um indivíduo se coloca, e as conseqüentes conclusões alcançadas, manifestam mecanismos ou formas de pensamento particulares presentes na comunidade da qual faz parte. O essencial é identificar a existência de algo externo ao âmbito individual, que fundamenta relações singulares entre a agência e a estrutura. É exatamente o entendimento dessas relações que pode revelar os modos de pensamento e os meios disponíveis, legítimos e justificados para a ação dos homens. 


\section{NOTAS}

1. Parte dessa discussão desenvolve-se a partir da concepção de racionalidade limitada de Herbert Simon (1967), segundo a qual as escolhas individuais são caracterizadas pela limitação da capacidade cognitiva, fundada pela falta de conhecimento e de informações. Nessas condições, os agentes adotariam uma conduta de "satisfação", em vez de uma tentativa de maximização ilimitada. Simon (idem:271) caracteriza a satisfação como um mecanismo baseado em seqüências curtas de decisão, o que pressupõe inércia dos sujeitos em condições incertas. Levando em conta aspectos psicológicos, sugere-se que há limites internos para a conduta instrumental, muito além das restrições externas, como preços, oferta e demanda. Entretanto, deve-se notar que o comportamento de satisfação nada mais é do que uma reflexão premeditada de como construir decisões ótimas em ambientes de informações limitadas. Adespeito da grande influência dos trabalhos de Simon no campo da escolha racional, não aprofundo suas teses neste artigo devido ao fato de ressaltarem, sobretudo, aspectos não-sociológicos de uma psicologia da ação e da construção individual de modelos mentais.

2. Outro estudo fundamental sobre a temática da confiança e das possibilidades de cooperação em contextos sociais que podem prescindir dos aparelhos formalizados do Estado é o de Michael Taylor (1987).

3. Rapoport é o formulador da temática estratégica do tit for tat aplicada por Axelrod. O autor tem importância decisiva no debate sobre alguns limites da concepção tradicional de racionalidade utilizada pela teoria dos jogos. Todavia, suas proposições críticas remetem, substantivamente, a fatores psicológicos, destacando os aspectos sensoriais da percepção, da perspectiva individual e da persuasão mental. 


\section{REFERÊNCIAS BIBLIOGRÁFICAS}

AXELROD, Robert. (1984), The Evolution of Cooperation. New York, Basic Books.

BOUDON, Raymond. (1991), "Individualisme et Holisme dans les Sciences Sociales", in P. Birnbaum e J. Leca (orgs.), Sur L'Individualisme. Paris, Presses de la Fondation Nationale des Sciences Politiques.

. (1999), Le Sens des Valeurs. Paris, PUF.

. (2002), "Théorie du Choix Rationnel ou Individualisme Méthodologique?". Sociologie et Sociétés, vol. XXXIV, no 1, pp. 9-32.

. (2003), Raison, Bonnes Raisons. Paris, PUF.

BOURDIEU, Pierre. (1977), Algérie 60: Structures Économiques et Structures Temporelles. Paris, Les Éditions de Minuit.

CASTORIADIS, Cornelius. (1982) [1975], A Instituição Imaginária da Sociedade. Rio de Janeiro, Paz e Terra.

CHERKAOUI, Mohamed. (2003), "Les Transitions Micro-Macro. Limites de la Théorie du Choix Rationnel dans le Foundations of Social Theory". Revue Française de Sociologie, vol. 44, no 2 , pp. 231-255.

COLEMAN, James S. (1990), Foundations of Social Theory. Cambridge, Harvard University Press.

DOMINGUES, José Maurício. (1995), Sociological Theory and Collective Subjectivity. Hampshire, Palgrave.

ELSTER, Jon. (1983), Sour Grapes. Studies in the Subversion of Rationality. Cambridge, Cambridge University Press.

. (1984), Ulysses and the Sirens. Studies in Rationality and Irrationality (edição revista). Cambridge/Paris, Cambridge University Press/Éditions de la Maison des Sciences de L'Homme.

. (2000), "Rational Choice History: A Case of Excessive Ambition". The American Political Science Review, vol. 94, no 3, pp. 685-695.

GELLNER, Ernest. (1991), “L'Animal qui Évite les Gaffes, ou un Faisceau d'Hypothèses", in P. Birnbaum e J. Leca (orgs.), Sur L'Individualisme. Paris, Presses de la Fondation Nationale des Sciences Politiques.

GODELIER, Maurice. (1974), Rationalité et Irrationalité en Économie - II. Paris, François Maspero.

GREEN, Donald e SHAPIRO, Ian. (1994), Pathologies of Rational Choice: A Critique of Applications in Political Science. New Haven, Yale University Press.

HARDIN, Russell. (1988), Morality within the Limits of Reason. Chicago, The University of Chicago Press.

(1995), One for All. The Logic of Group Conflict. Princeton, Princeton University Press.

HEAP, Shaun Hargreaves e VAROUFAKIS, Yanis. (1995), Game Theory: A Critical Introduction. London, Routledge. 
HINDESS, Barry. (1988), Choice, Rationality, and Social Theory. London, Unwin Hyman.

LATOUCHE, Serge. (2001), La Déraison de la Raison Économique. Du Délire d'Efficacité au Principe de Précaution. Paris, Éditions Albin Michel.

MEYER, John. (1987), "Self and Life Course: Institutionalization and Its Effects", in J. Meyer, J. Boli, F. Ramirez e G. Thomas (eds.), Institutional Structure: Constituting State, Society, and the Individual. Newbury Park, Sage Publications.

OPP, Karl-Dieter. (2001), "How do Norms Emerge? An Outline of a Theory", in R. Boudon, P. Demeulenaere, R. Viale (orgs.), L'Explication des Normes Sociales. Paris, PUF.

PARETO, Vilfredo. (1968) [1916], Traité de Sociologie Générale. Genève, Librairie Droz.

PARSONS, Talcott. (1968) [1949], The Structure of Social Action: A Study in Social Theory with Special Reference to a Group of Recent Writers. New York, Free Press.

POLANYI, Karl. (1957), "The Economy as Instituted Process", in K. Polanyi, C. M. Arenserg e H. W. Pearson (eds.), Trade and Market in the Early Empires. Economies in History and Theory. New York/London, The Free Press/Collier-Macmillan Limited.

RAPOPORT, Anatol. (1980) [1974], Lutas, Jogos e Debates. Brasília, Editora UnB.

SAHLINS, Marshall. (1976), Culture and Practical Reason. Chicago, The University of Chicago Press.

SIMON, Herbert A. (1967), Models of Man. New York, John Wiley \& Sons.

SMITH, John Maynard. (1982), Evolution and the Theory of Games. Cambridge, Cambridge University Press.

TAYLOR, Michael. (1987), The Possibility of Cooperation. Cambridge, Cambridge University Press.

ULLMANN-MARGALIT, Edna. (1977), The Emergence of Norms. Oxford, Oxford University Press.

WEBER, Max. (1968), Economy and Society. New York, Bedminster Press. . (1996) [1904], A Ética Protestante e o Espírito do Capitalismo. São Paulo, Livraria Pioneira Editora.

WOLFELSPERGER, Alain. (2001), “La Modélisation Économique de la Rationalité Axiologique. Des Sentiments Moraux aux Mécanismes Sociaux de la Moralité", in R. Boudon, P. Demeulenaere e R. Viale (orgs.), L'Explication des Normes Sociales. Paris, PUF. 


\section{ABSTRACT \\ Social Conditions for Instrumental Action: Problems in the Sociological Conception of the Rational Choice Theory}

This article critically analyzes new sociological approaches to the rational choice theory which - beyond examining political or economic practices link the notion of instrumental rationality to social issues and themes. The article begins by highlighting the issue of trust, indicating the functionality of certain social arrangements in collective problem-solving. The paper goes on to demonstrate that problems emerge with the theory when it attempts to explain the feasibility of social norms in impersonal, comprehensive contexts. Thus, the fundamental point that appears to be missing from rational choice theory is the perception that individual decisions and instrumental conduct itself incorporate dispositions that in a sense are beyond the actors' control.

Key words: rational choice; social theory; individualism; rationality

\section{RÉSUMÉ}

Conditions Sociales de l'Action Instrumentale: Problèmes dans la Conception Sociologique de la Théorie du Choix Rationnel

Dans cet article, on fait la critique des nouvelles approches sociologiques de la théorie du choix rationnel lesquelles, au-delà de l'examen des pratiques politiques ou économiques, relient la notion de rationnalité instrumentale à des questions et des thèmes sociaux. On remarque, d'abord, le thème de la confiance, qui montre la fonctionnalité de certains arrangements sociaux dans leur solution des problèmes de l'action collective. On montre, pourtant, que les problèmes de la théorie surgissent lorsqu'on essaie d'expliquer l'applicabilité des normes sociales dans des contextes impersonnels et plus larges. Ainsi, le point fondamental qui semble absent de la théorie sociale du choix rationnel est la perception que les décisions individuelles, ainsi que la conduite instrumentale, assimilent des dispositions qui sont, d'une certaine façon, hors du contrôle des agents.

Mots-clé: choix rationnel; théorie sociale; individualisme; rationnalité 